Original Research Paper

\title{
Spatial Pattern of Natural Spread of Rice False Smut (Ustilaginoidea virens) Disease in Fields
}

\author{
${ }^{1,2}$ Bodrun Nessa, ${ }^{3}$ Moin U. Salam, ${ }^{1}$ A.H.M. Mahfuzul Haque, ${ }^{2}$ Jiban K. Biswas, ${ }^{2}$ M. Shahjahan Kabir, \\ ${ }^{3}$ William J. MacLeod, ${ }^{3}$ Mario D'Antuono, ${ }^{2}$ Hirendra N. Barman, ${ }^{2}$ M. Abdul Latif and ${ }^{3}$ Jean Galloway \\ ${ }^{1}$ Department of Plant Pathology and Seed Science, Sylhet Agricultural University, Tilagor, Sylhet-3100, Bangladesh \\ ${ }^{2}$ Bangladesh Rice Research Institute, Gazipur-1701, Bangladesh \\ ${ }^{3}$ Department of Agriculture and Food Western Australia, 3 Baron-Hay Court, South Perth, WA 6151, Australia
}

Article history

Received: 2-3-2015

Revised: 23-3-2015

Accepted: $20-5-2015$

Corresponding Author:

Moin U. Salam

Department of Agriculture and

Food Western Australia, 3

Baron-Hay Court, South Perth,

WA 6151, Australia

Tel: +61 893683161

Fax: +61893683082

Email: moinsalam1@gmail.com

\begin{abstract}
Pattern of disease spread provides improved knowledge on how the pathogen introduces itself and interacts with environment in fields and expresses as a disease. It is especially significant when epidemiology of a disease, such as Rice False Smut (RFSm), is unclearly understood. Not reported before, this study attempted an analysis of spatial pattern of natural spread of RFSm in nine fields in an intensive rice ecosystem in Bangladesh. Both conventional and specialized statistical methods were applied in the analysis. Results show that the spread of the disease was not similar between and within the fields and even some fields were almost disease free. RFSm recorded aggregation in spaces in most of the fields, but the location of this aggregation differed between the fields. Symptom recorded on panicles in regenerated tillers from harvested main crop (otherwise known as ratoons). The disease tended to be prominent towards proximity of drainage channels. The probability of occurring one diseased tiller per hill was calculated as $73 \%$ and cumulative probability of four or less smut balls per diseased panicle as little over $60 \%$. This study establishes soil as the absolute dominant source of initiation of the epidemic. The analysis did not find evidence of any long- or short-distance primary and/or secondary sources of infection. It is concluded that the disease management be directed specific to the fields at risk. It suggests development of a soil testing tool for quantifying inoculum potential in a field to ascertain the risk. With the discovery of symptom on ratoons, this study highlights the need for fresh thinking on identifying the pathway of entry of the pathogen into the plant.
\end{abstract}

Keywords: Aggregation, False Smut, Natural Spread, Rice, Spatial Pattern, Smut Ball, Ustilaginoidea virens

\section{Introduction}

Knowledge of disease spread provides clues to method of pathogen introduction and its interaction with environment in fields. Spatial and temporal analysis of a disease can be used to test hypotheses on the dynamics of spread including those concerned with the importance of primary and secondary inoculum and mechanisms involved in the spread of the pathogen (Moreno et al., 2007). This analysis that aids understanding and managing epidemics (Taylor, 1984; Nelson and Campbell, 1993; Camann et al., 1995) is especially helpful to deal with new diseases or those whose epidemiology is least understood.
Rice False Smut (RFSm) is not a new disease. This fungal disease (anamorph: Ustilaginoidea virens (Cooke) Takah.; teleomorph: Villosiclava virens (Nakata) E. Tanaka \& C. Tanaka) was first reported in 1878 in India (Tanaka et al., 2008). Its importance has risen recently with the change of its status from "minor" to "major" causing concern in almost all the rice growing countries across the globe (see details in Nessa et al., 2015). A "major" disease usually affects yield, as has been reported for RFSm in many literature (Nessa et al., 2015). Besides, a disease, when impacts yield, also reduces the economic sustainability of a crop by lowering farmers' income (Kuosmanen et al., 2013; Spiertz, 2013; Testa et al., 2014; Sgroi et al., 2015). 
RFSm is a unique disease in the sense that symptoms are only visible after flowering, where the fungus infects individual spikelet and replaces the seed with a large velvety orange to green ball, commonly known as "smut ball". Its epidemiology with respect to inoculum source (s), dispersion and point of entry of the pathogen into plant and overall infection process is still on debate (Lee and Gunnell, 1992; TeBeest et al., 2010; Guo et al., 2012; Tang et al., 2013; Fan et al., 2014). These information gaps hinder formulating essential options for disease management in farmers' field.

Because of the uniqueness in timing of symptom visibility, it is perhaps less important studying the incrop temporal dynamics of the disease. However, the spatial pattern of spread of the disease in the fields, where rice is grown in natural environment, can provide essential information on key epidemiological processes as has been reported for other diseases (Campbell and Noe, 1985; Madden et al., 1987; Hughes, 1990; Nelson and Campbell, 1993; Camann et al., 1995; Madden et al., 1995; Savary et al., of this work was to try to understand what major 2001; Moreno et al., 2007). To best of our knowledge, there has been no published report on analysis of spatial pattern of natural spread of rice false smut disease. The aim factors driving RFSm epidemics in the ecosystem under study. This information will be valuable for formulating and implementing management measures to reduce crop damage and guide future research on specific epidemiological aspects.

\section{Materials and Methods}

\section{Definition}

Brief explanation of the terms used in this article as follows:

- Aggregation: Clustering in space and its use here is synonymous with the terms "heterogeneity", "overdispersion", "clustering", "clumping" and "contagion" (Madden et al., 2007)

- Ascospore: Sexual spore of rice false smut pathogen develop from sclerotia (the sexual fruiting bodies of the fungus)

- Chlamydpospore: Asexual spore of rice false smut pathogen.

- Diseased hill: A hill contained one or more diseased tiller

- Diseased tiller: A tiller whose panicle (inflorescence) bearing at least one smut ball

- Healthy hill: A hill contained no diseased tiller

- Healthy tiller: A tiller whose panicle (inflorescence) bearing no smut ball

- Hill: A clump of rice tillers

- Pattern: Dispersion in space of diseased hills infected by rice false smut pathogen
- Ratoon: Volunteer re-generated tillers develop from the harvested tillers of the main crop

- Smut ball: Visually shown velvety orange or green ball on panicles of rice tillers as a result of infection by rice false smut pathogen

- Spore: A propagule of rice false smut pathogen, either ascospore or chlamydospore

\section{The Study Area and Rice Crops}

Data for this study were collected from the experimental farm, called "West Byde", of the Bangladesh Rice Research Institute (BRRI), Gazipur, Bangladesh, located at $23^{\circ} 59^{\prime} \mathrm{N}$ latitude, $90^{\circ} 24^{\prime} \mathrm{E}$ longitude. This farm has built up as an intensive riceecosystem in the last 40 years growing as many as three rice crops annually in 88 fields spread over 35 hectare area (Fig. 1). This site is about $35 \mathrm{~m}$ above the mean sea level and has a subtropical climate, which is strongly influenced by the south-western monsoon. The average annual rainfall is $2000 \mathrm{~mm}$ with more than $80 \%$ of it occurring during mid-June to the end of September. Mean temperature is the lowest $\left(15^{\circ} \mathrm{C}\right)$ in January and the highest $\left(30^{\circ} \mathrm{C}\right)$ in May (see detail in Nessa et al., 2015).

Monsoonal rice (locally known as "transplanted Aman" or "T. Aman") was grown in all the seven fields (marked in number Fig. 1) as hand-transplanted during July-August 2014 using about 30 day-old seedlings. The segmented field, where the disease on ratoon hills was studied, was transplanted in 15 June and 15 July (marked in " $R$ " in Fig. 1). Two or three seedlings were transplanted per hill maintaining a hill-to-hill distance of $20 \mathrm{~cm}$ and line-to-line distance of $20 \mathrm{~cm}$. Field size varied between $5 \mathrm{~m} \times 4 \mathrm{~m}$ to $400 \mathrm{~m} \times 250 \mathrm{~m}$. Rice variety "BRRI dhan49" was used in all the fields from where data were collected. This variety has a history of susceptibility of the disease. The crops were fertilized with recommended doses of Nitrogen (N) $\left(200 \mathrm{~kg} \mathrm{ha}^{-1}\right.$ as urea), Phosphorus (P) (63 kg ha $\mathrm{kg}^{-1}$ as triple super phosphate), potassium (K) (84 kg ha ${ }^{-1}$ as muriate of potash) and Sulphur (S) (56 kg ha $\mathrm{kg}^{-1}$ gypsum) (BRRI, 2013). Nitrogen was top dressed in three equal splits: 20, 35 and 50 Days After Transplanting (DAT), whereas $\mathrm{P}, \mathrm{K}$ and $\mathrm{S}$ were applied once, during final land preparation. The crops received moisture predominantly through monsoonal rains, but supplemented by irrigation water to maintain a water level of 2 to $3 \mathrm{~cm}$. Management of the crops included manual weed control twice, at 30 and 45 DAT. No chemicals, insecticides or fungicides, were used for pest and disease control. No artificial or additional inoculum added anywhere in the ecosystem to modify natural disease pressure.

Smut balls on ratoons were monitored in two plots, transplanted on 15 June and nine plots, transplanted on 15 July, with the same variety in the same season described above. The cultivation procedure and crop management practices in these plots were the same as described above. The plot size was $2.5 \mathrm{~m} \times 2.5 \mathrm{~m}$. 


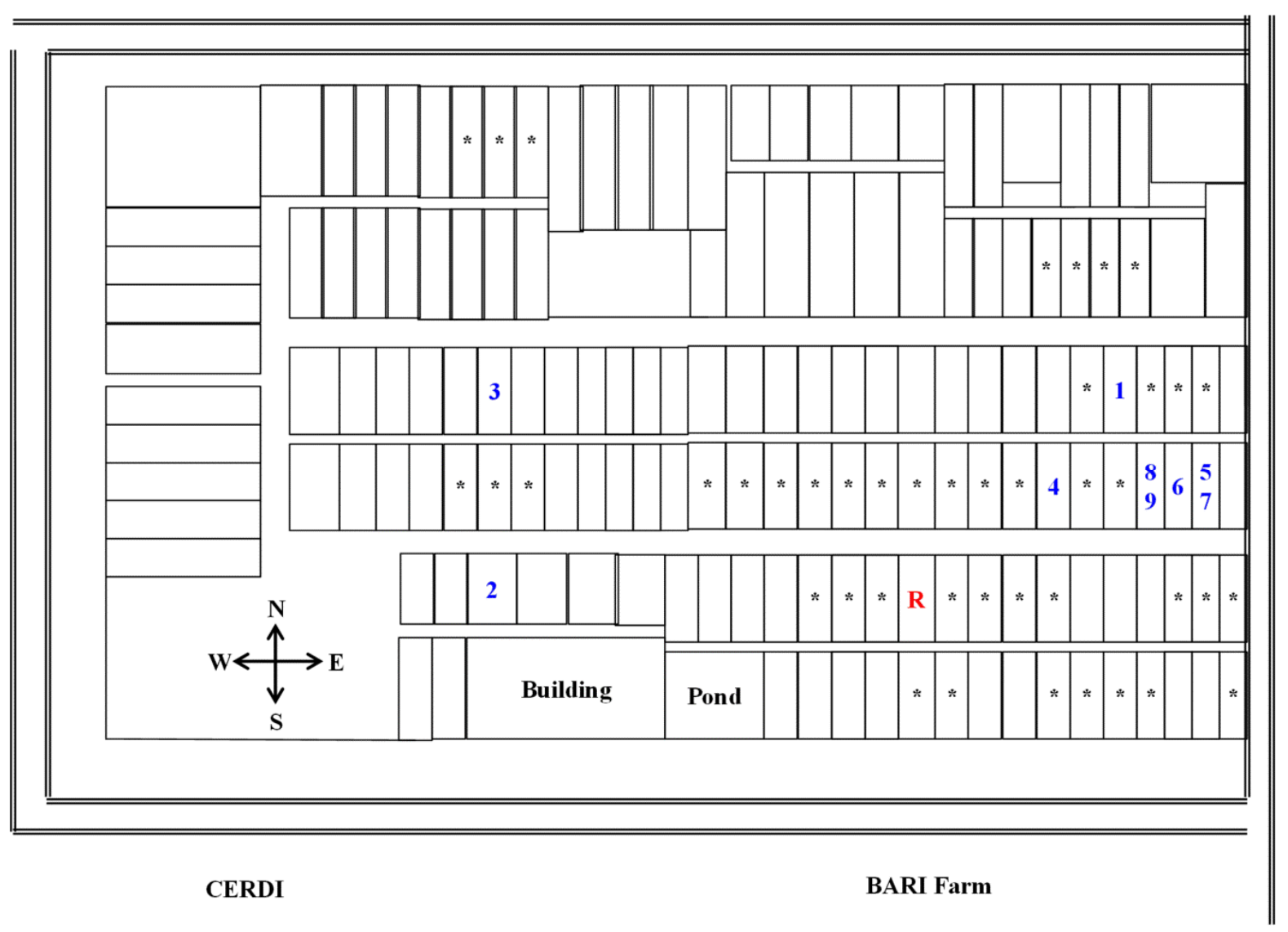

Fig. 1. Rice fields (marked in number) in the "West Byde" section of the experimental farm of the Bangladesh Rice Research Institute, Gazipur, Bangladesh, from where data were collected. The asterisks indicate the fields where the rice false smut disease was recorded. The field with " $R$ " symbol is the location where the disease was recorded in the ratoon crop

The hills in the main crops were harvested at maturity by manually cutting the tillers at $40-60 \mathrm{~cm}$ height. No additional crop management practices were applied for ratoons, except maintaining a water level of 2 to $3 \mathrm{~cm}$ through irrigation. Panicles on the ratoons emerged and developed during December in the same year.

\section{Data Collection and Statistical Analysis}

\section{Spatial Pattern Analysis}

Each field was divided into nine equal sized quadrats along north-south and east-west direction (North-East (NE), North-Central (NC), North-West (NW), East-Central (EC), Central (C), West-Central (WC), South-East (SE), South-Central (SC) and South-Western (SW)). Each hill in the quadrats were inspected physically and scored by count by the number of diseased tillers. A hill was scored as zero (0) if no tiller showed smut balls in the panicles. The sample size in a quadrat and the fields are presented in Table 1. This data were collected in the final week of panicle maturation stage during the first two weeks of
October, except for Field 2, where panicle maturation occurred late during the end of October.

Position of each hill in nine fields was plotted in MS Excel 2010, designating blank for healthy hill and filled circle for diseased hills. Diseased hills were categorized into three: 1 (blue), 2 (yellow) and 3 or more (red) diseased tillers per hill. Each field is presented in proportion of dimension of samples as presented in Table 1. The averages and standard deviations of diseased hills and diseased tillers per hill were calculated for each field and represented in XY graph to show cluster and/or diversity of the disease status between the fields. A standard Generalized Linear Modeling (GLM) procedure was applied using GenStat for Windows (http://www.genstat.co.uk; 17th Edition) to fit a multinomial distribution to the number of hills with 0 , 1,2 and 3 or more diseased tillers across nine equal size $(3 \times 3)$ quadrats from each rectangular field (Payne, 2014). The $\chi^{2}$ test were used to compare the overall difference between the multinomial distributions across nine quadrats in each field. Approximate t-tests $(\mathrm{Pt})$ were shown to compare the multinomial scores for a quadrat in a field to the central quadrat. 
Table 1. Dimension of each quadrat (number of hills along length $(\mathrm{X}) \times$ number of hills along width $(\mathrm{Y})$ ), number of hills sampled in each quadrat (Sample) and total number of hills sampled (Field total) in nine fields for analyzing spatial pattern of natural spread of rice false smut disease

\begin{tabular}{|c|c|c|c|c|c|c|c|c|c|}
\hline Quadrat & Field 1 & Field 2 & Field 3 & Field 4 & Field 5 & Field 6 & Field 7 & Field 8 & Field 9 \\
\hline Dimension & $14 \times 21$ & $9 \times 15$ & $7 \times 4$ & $3 \times 10$ & $6 \times 3$ & $6 \times 3$ & $5 \times 3$ & $5 \times 3$ & $5 \times 3$ \\
\hline Sample & 294 & 210 & 28 & 30 & 18 & 18 & 15 & 15 & 15 \\
\hline Field total & 2646 & 1890 & 252 & 270 & 162 & 162 & 135 & 135 & 135 \\
\hline
\end{tabular}

\section{Smut Ball on Ratoons}

Ratoons were monitored in the 11 observation plots in every alternate day during December 2014 through to mid-January 2015. Data on total hills, diseased hills (in the main crop) and diseased ratoon hills in each observation plot was recorded by count. These data were analyzed as percentage of diseased hills in the main crop and in the ratoon crop and compared at 95\% Confidence Interval (CI) using in-built formula in MS Excel 2010.

\section{Diseased Hills Versus Diseased Tillers Per Hill}

Data collected for spatial analysis were averaged by quadrat for diseased hills and diseased tillers per hill. Regression analysis was performed using these data from seven fields (Fields 1 through to 7) using "Analysis Tool" package in MS Excel 2010. Data from Field 8 and 9 were not used due to status of zero diseased hills in the many quadrats.

\section{Diseased Hills in the Proximity of Drainage Channel}

Diseased hills were recorded by count along the visible drainage channels in Fields 1-4, 6 and 7. In the rest of three fields, there was no recognizable drainage channel. The closest hills were located in the vicinity of about $50 \mathrm{~cm}$ from the center of the channels. Hills were counted by the row distance $(20 \mathrm{~cm})$ up to $150 \mathrm{~cm}$ distance. The data were expressed as percentage of diseased hills and subjected to regression analysis using “Analysis Tool” package in MS Excel 2010.

\section{Cumulative Probability of Diseased Tillers Per Hill and Smut Balls Per Panicle}

Data previously collected for spatial analyses were used to calculate the cumulative probability of number of diseased tillers per hill in the ecosystem. For undertaking the same analysis on smut balls per panicle, 672, 183, 230 and 262 (total 1337) diseased panicles were collected randomly from Field 1, 2, 3 and 4, respectively. Smut balls on each panicle were counted and used to calculate the cumulative probability.

\section{Results}

Diseased Hills and Number of Diseased Tillers Within a Hill - Descriptive Statistics

The natural occurrence of Rice False Smut (RFSm) disease as it appeared in nine fields in the intensive rice ecosystem is presented in Fig. 2. In the ecosystem, about $30 \%$ (with a standard deviation of $21.8 \%$ ) of the hills were recorded as diseased, affecting 1.3 (with a standard deviation of 0.4 ) tillers in each hill (Figs. 3a and b). The status of the disease was not similar across the fields. Fields 2 and 4 had high level of diseased hills (52-55\%), whereas few in Fields 8 and 9 (4-7\%) and moderate in Fields 3, 5, 6 and 7 (33-36\%). Field 1 had about 24\% hills diseased (Fig. 3a). Within a field, high variability was observed in Fields 3, 6 and 7 (23-24\% as standard deviation), but relatively low in the rest $(<14 \%)$. More tillers within a diseased hill was recorded in Fields 2 and 3 ( $\sim 1.8$ by number) than rest of the fields (1.0-1.3). High variability in the number of diseased tiller per hill was recorded in Field 3 ( 0.7 by number) compared to rest of the fields $(<=0.4)$ (Fig. 3b).

The spatial pattern of RFSm spread within a field was not similar across the nine fields. Field 1 had more diseased hills in Central (C) and South-Central (SC) quadrats $(\sim 34 \%)$ than other quadrats. The highest proportion of diseased hills (76\%) was recorded in Field 2 in the South-West (SW) quadrat and the lowest (35\%) in the North-East (NE). This was exactly the opposite to what was observed in Field 3, the highest (71\%) in the NE and the lowest (14\%) in the SW. Fields 4 and 5 had largely similar pattern of RFSm spread across the nine quadrats, except for East-Center (EC) of Field 5 where the disease was extremely low (6\%). On the contrary, the EC quadrat in Field 6 had more $(72 \%)$ diseased hills. The spatial pattern of diseased hills in Field 5 and 7 was similar, although the magnitude of the disease status was lower in Field 7. The spatial pattern of diseased tillers within a hill was largely similar in nine fields except for Field 2 and 3. Fields 2 and 3 had more diseased tillers within a hill and the pattern of spread in nine quadrats was almost similar to that of diseased hills within the respective fields.

\section{Spatial Pattern of Disease Occurrence}

Of the six fields subjected to Generalized Linear Modeling (GLM), the disease in nine quadrats within four fields (Fields 1, 2, 3 and 6) were overall significantly different $\left(\chi^{2}<0.001\right)$, indicating the disease aggregated in some quadrats; whereas, there was no evidence to prove such aggregation in Field $4\left(\chi^{2}<0.281\right)$ and Field 5 $\left(\chi^{2}<0.317\right)$ (Table $2 \mathrm{a}$ and $\left.\mathrm{b}\right)$. Figure 4 shows that the disease aggregation in the North-East (NE), NorthWest (NW) and South-Central (SC) quadrats were similar to the Central (C) quadrat in Field 1. 

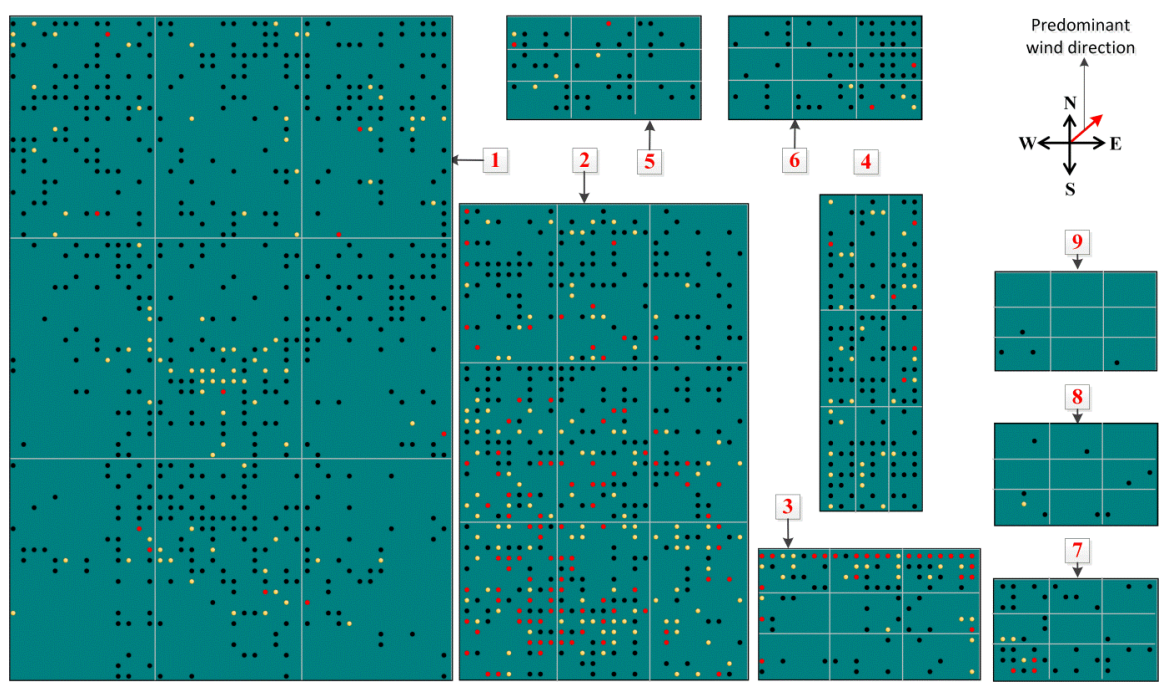

8

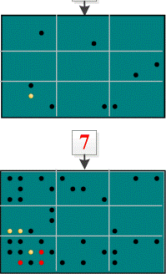

Fig. 2. Spatial pattern of spread of rice false smut disease across nine quadrats (thin line within a field) in each of the nine fields (marked in number). Each point represents a hill. Black, yellow and red filled-circles denote for, respectively, one, two and three or more diseased tillers per hill. Blank spaces are the locations of healthy hills
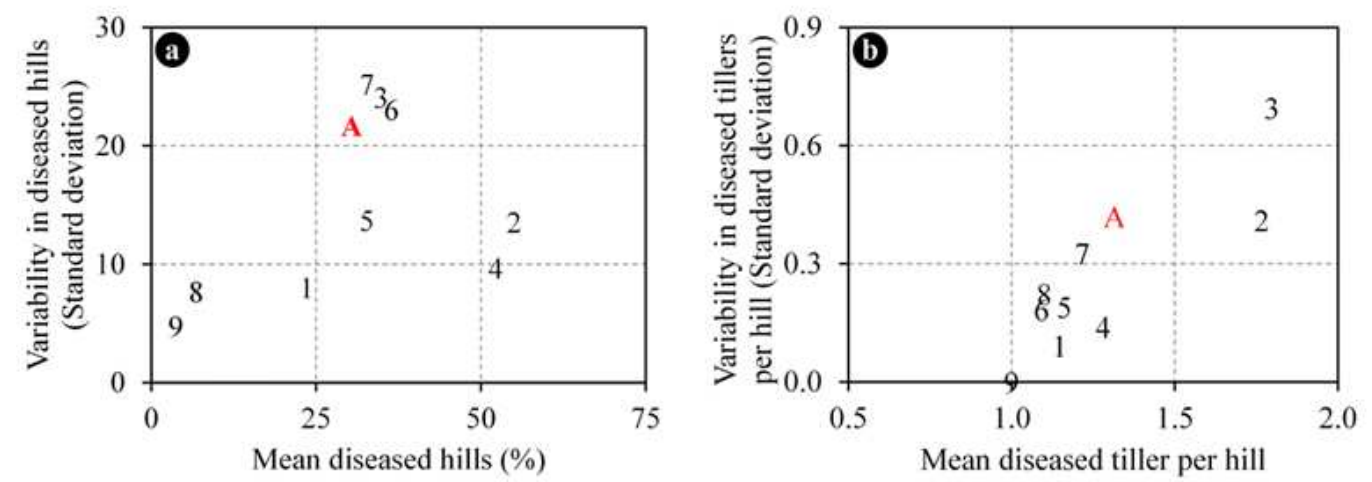

Fig. 3. Variation in the spread of rice false smut disease within (y-axis) and between (x-axis) nine fields (marked in number) with respect to percentage of diseased hills (a) and number of diseased tillers per hill (b). "A" indicates the average of percentage of diseased hills and/or the number of diseased tillers per hill across the nine fields

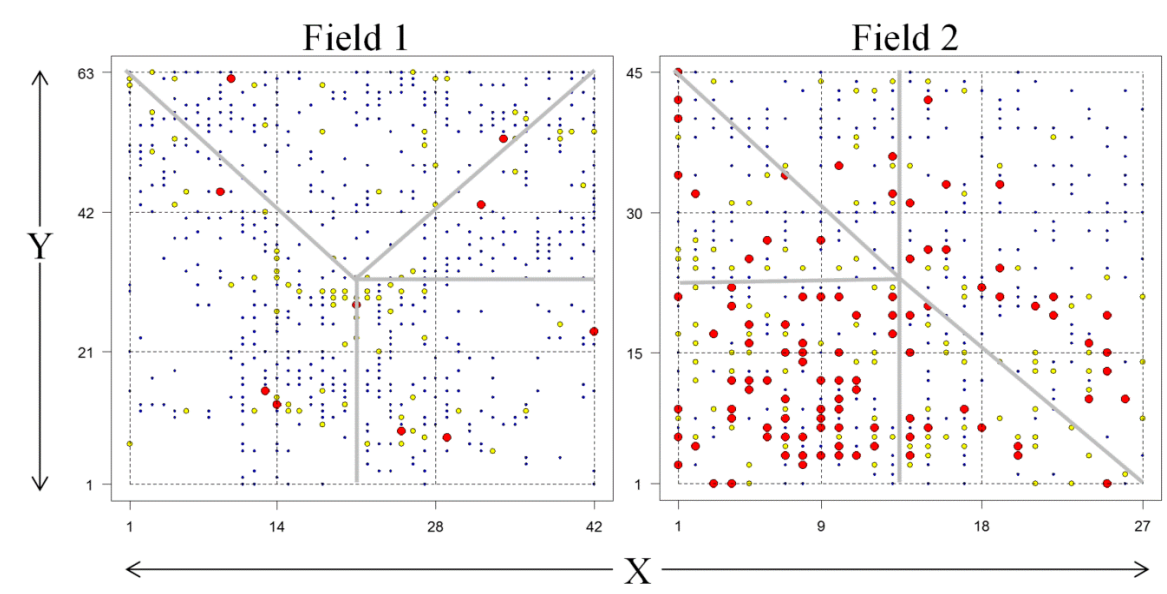

Fig. 4. Spread of rice false smut disease across nine quadrats in two big fields 1 and 3. The quadrats joining blue lines within a field indicate statistically similar pattern of disease spread to the central quadrat of the field 
Table 2a. Estimates (Est), Standard Error (SE), t-statistics ( $\mathrm{t}$ ) and probability (Pt) of multinomial logit function (GLM) comparing pattern of spread of rice false smut (RFSm) disease in eight quadrats relative to the central quadrat in Field 1,2 and 3. The $\chi^{2}$ test to compare the overall quadrats indicates the overall probability of the multinomial distribution of four RFSm levels $(0,1,2$ and 3 or more diseased tillers per hill) is homogeneous in a field. Quadrat NE is north-east, NC is north-central, NW is north-west, EC is east-central, C is central, WC is west-central, SE is south-east, SC is south-central and SW is south-western quadrat in each field

\begin{tabular}{|c|c|c|c|c|c|c|c|c|c|c|c|c|}
\hline \multirow[b]{2}{*}{ Quadrat } & \multicolumn{4}{|c|}{ Field 1} & \multicolumn{4}{|c|}{ Field 2} & \multicolumn{4}{|c|}{ Field 3} \\
\hline & Est & $\mathrm{SE}$ & $\mathrm{t}$ & $\mathrm{Pt}$ & Est & SE & $\mathrm{t}$ & $\mathrm{Pt}$ & Est & $\mathrm{SE}$ & $\mathrm{t}$ & $\mathrm{Pt}$ \\
\hline$\overline{\mathrm{NE}}$ & -0.21 & 0.18 & -1.16 & 0.25 & -0.81 & 0.26 & -3.15 & 0.00 & 2.70 & 0.61 & 4.40 & $<0.001$ \\
\hline $\mathrm{NC}$ & -0.36 & 0.19 & -1.95 & 0.05 & -0.32 & 0.24 & -1.33 & 0.18 & 2.36 & 0.61 & 3.87 & $<0.001$ \\
\hline NW & 0.06 & 0.18 & 0.32 & 0.75 & -0.42 & 0.24 & -1.71 & 0.09 & 2.06 & 0.61 & 3.39 & $<0.001$ \\
\hline $\mathrm{EC}$ & -0.45 & 0.19 & -2.37 & 0.02 & -0.51 & 0.25 & -2.05 & 0.04 & 0.48 & 0.66 & 0.73 & 0.47 \\
\hline $\mathrm{C}$ & - & - & - & - & - & - & - & - & - & - & - & - \\
\hline WC & -0.64 & 0.19 & -3.30 & $<0.001$ & 0.35 & 0.23 & 1.53 & 0.13 & 0.26 & 0.68 & 0.38 & 0.70 \\
\hline SE & -1.07 & 0.21 & -5.05 & $<0.001$ & -0.43 & 0.25 & -1.76 & 0.08 & 0.04 & 0.70 & 0.05 & 0.96 \\
\hline $\mathrm{SC}$ & 0.02 & 0.18 & 0.10 & 0.92 & 0.41 & 0.23 & 1.77 & 0.08 & -0.03 & 0.71 & -0.05 & 0.96 \\
\hline SW & -0.85 & 0.20 & -4.21 & $<0.001$ & 0.51 & 0.23 & 2.20 & 0.03 & -0.24 & 0.73 & -0.32 & 0.75 \\
\hline $\begin{array}{l}\text { Overall } \chi^{2} \\
\text { between } \\
\text { quadrats }\end{array}$ & & $\mathrm{p}<0.001$ & & & & $\mathrm{p}<0.001$ & & & & $\mathrm{p}<0.001$ & & \\
\hline
\end{tabular}

Table 2b. Estimates (Est), Standard Error (SE), t-statistics ( $\mathrm{t}$ ) and probability (Pt) of Multinomial Logit Function (GLM) comparing pattern of spread of Rice False Smut (RFSm) disease in eight quadrats relative to the central quadrat in Field 4, 5 and 6.The $\chi^{2}$ test to compare the overall quadrats indicates the overall probability of the multinomial distribution of four RFSm levels $(0,1,2$ and 3 or more diseased tillers per hill) is homogeneous in a field. Quadrat NE is north-east, NC is north-central, NW is north-west, EC is east-central, C is central, WC is west-central, SE is south-east, SC is south-central and SW is south-western quadrat in each field

\begin{tabular}{|c|c|c|c|c|c|c|c|c|c|c|c|c|}
\hline \multirow[b]{2}{*}{ Quadrat } & \multicolumn{4}{|c|}{ Field 4} & \multicolumn{4}{|c|}{ Field 5} & \multicolumn{4}{|c|}{ Field 6} \\
\hline & Est & $\mathrm{SE}$ & $\mathrm{t}$ & $\mathrm{Pt}$ & Est & SE & $\mathrm{t}$ & $\mathrm{Pt}$ & Est & SE & $\mathrm{t}$ & $\mathrm{Pt}$ \\
\hline$\overline{\mathrm{NE}}$ & 0.55 & 0.49 & 1.11 & 0.27 & -0.07 & 0.74 & -0.10 & 0.92 & 1.49 & 0.71 & 2.11 & 0.04 \\
\hline $\mathrm{NC}$ & -0.50 & 0.52 & -0.96 & 0.34 & -0.28 & 0.76 & -0.36 & 0.72 & -0.29 & 0.78 & -0.38 & 0.71 \\
\hline NW & 0.18 & 0.50 & 0.37 & 0.71 & 0.57 & 0.70 & 0.82 & 0.41 & 0.00 & 0.75 & 0.00 & 1.00 \\
\hline $\mathrm{EC}$ & 0.37 & 0.50 & 0.75 & 0.45 & -1.91 & 1.16 & -1.65 & 0.10 & 1.84 & 0.72 & 2.57 & 0.01 \\
\hline $\mathrm{C}$ & - & - & - & - & - & - & - & - & - & - & - & - \\
\hline WC & 0.73 & 0.49 & 1.48 & 0.14 & 0.25 & 0.72 & 0.35 & 0.73 & -1.11 & 0.92 & -1.21 & 0.23 \\
\hline SE & -0.11 & 0.50 & -0.21 & 0.83 & -0.36 & 0.77 & -0.46 & 0.65 & 1.26 & 0.70 & 1.79 & 0.07 \\
\hline SC & 0.23 & 0.50 & 0.46 & 0.64 & 0.39 & 0.71 & 0.55 & 0.58 & 0.80 & 0.71 & 1.13 & 0.26 \\
\hline $\begin{array}{l}\text { SW } \\
\text { Overall } \chi^{2} \\
\text { between } \\
\text { quadrats }\end{array}$ & 0.64 & $\begin{array}{l}0.49 \\
\mathrm{p}<0.28\end{array}$ & 1.29 & 0.20 & 0.25 & $\begin{array}{l}0.72 \\
\mathrm{p}<0.32\end{array}$ & 0.35 & 0.73 & -0.29 & $\begin{array}{l}0.78 \\
p<0.001\end{array}$ & -0.38 & 0.71 \\
\hline
\end{tabular}

This pattern of aggregation was not similar in other fields. For example, Field 2 shows the disease aggregation in four quadrats (NW, North-Central (NC), West-Central (WC) and South-East (SE)) were similar to the central quadrat (Fig. 4). In Field 3, such aggregation in the northern quadrats was different to the other quadrats (Table 2a). The central quadrat in Field 6 shared a similar disease aggregation with all other quadrats except for the NE and EC (east-central).

Rice False Smut (RFSm) Carryover on ReGenerated Tillers (ratoons) in the Diseased Hills

In a surprising observation, the RFSm was recorded on the re-generated tillers (otherwise known as ratoons) in the harvested hills that were previously infected by the disease (Fig. 5). Smut balls were found in 11 plots, two of them were transplanted in 15 June and the nine in 15
July of 2014 growing season. Overall disease status in the main crops was low in these plots; however, over $25 \%$ of diseased hills from main crops produced smut balls in volunteer ratoons and the trend was similar in both transplanting dates (Fig. 6).

\section{Relationship between Intensity of Diseased Hills and Intensity of Smutted Tillers in the Diseased Hill}

There was a trend of increased smutted tillers in a hill with the intense the proportion of diseased hills. However, the number of diseased tillers per hill when regressed over the percentage of diseased hills accounted for only $32 \%$ of variance (adjusted $R^{2}=0.32$, slope $=0.013$, standard error of the slope $=0.002, n=63)$. As the standard error of the regression is very high $(0.36)$, it was not statistically evident that increased smutted tillers in a hill always resulted due to increased proportion of diseased hills. 

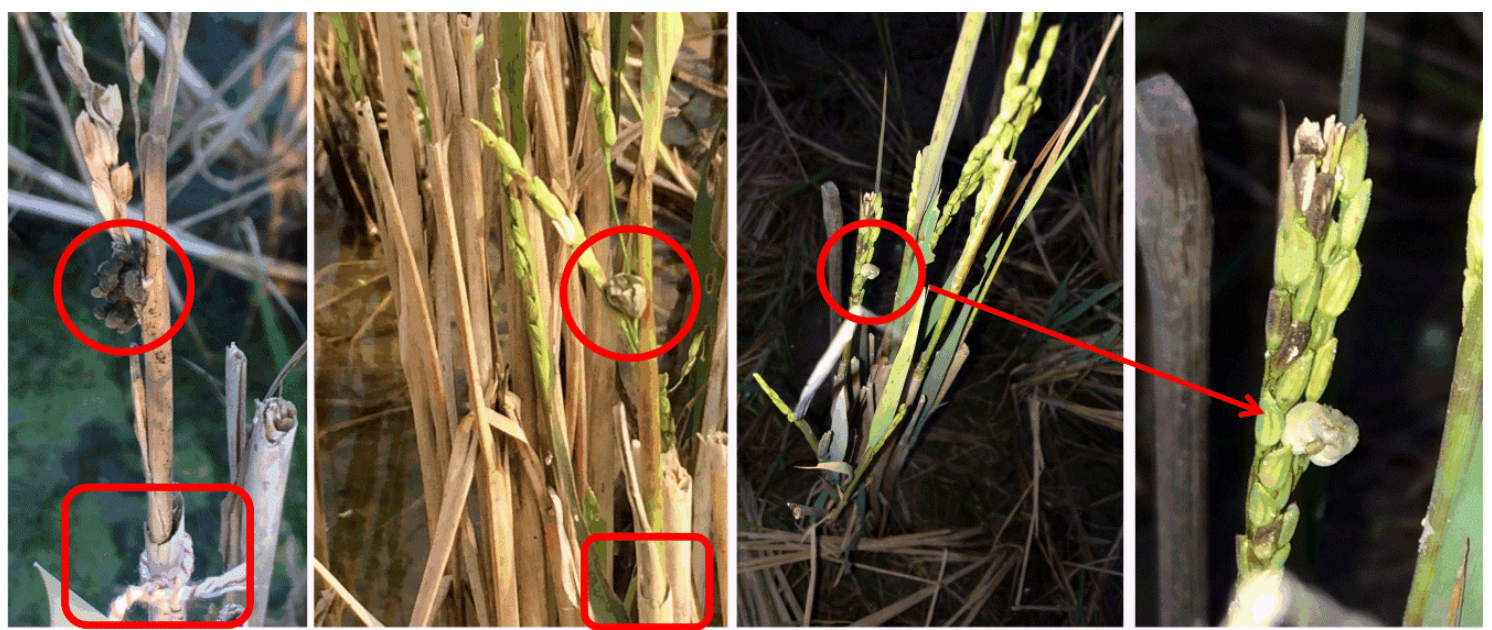

Fig. 5. Symptom as smut balls (circle) of rice false smut disease in the ratoons. Rectangles indicate the points of originating regenerated tillers from where the tillers of the main crop were harvested

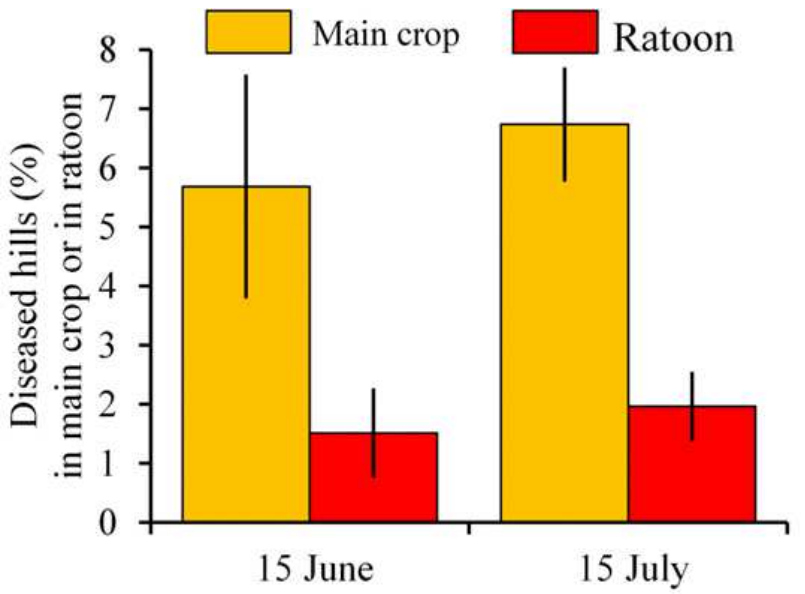

Transplanting time

Fig. 6. Percentage of diseased hills in the main crop and ratoon crop recorded at two time of transplanting. Vertical bars indicate the standard errors

\section{Relationship of Diseased Hills to the Proximity of Drainage Channel}

Rice hills near to drainage channel recorded with more disease than those far from drainage channel. A regression of percentage of diseased hills against the proximity of the location of the hills from drainage channel in a field explained $93 \%$ variability $\left(R^{2}=0.93\right.$, intercept $=82.39$, intercept standard error $=5.07$, slope $=$ 0.35 , slope standard error $=0.05, P<=0.05, n=6$ ). This analysis shows that for each $10 \mathrm{~cm}$ distance away from drainage channel (between 50 and $150 \mathrm{~cm}$ distance range), the percentage of diseased hills reduced by $7 \%$ (Fig. 7).

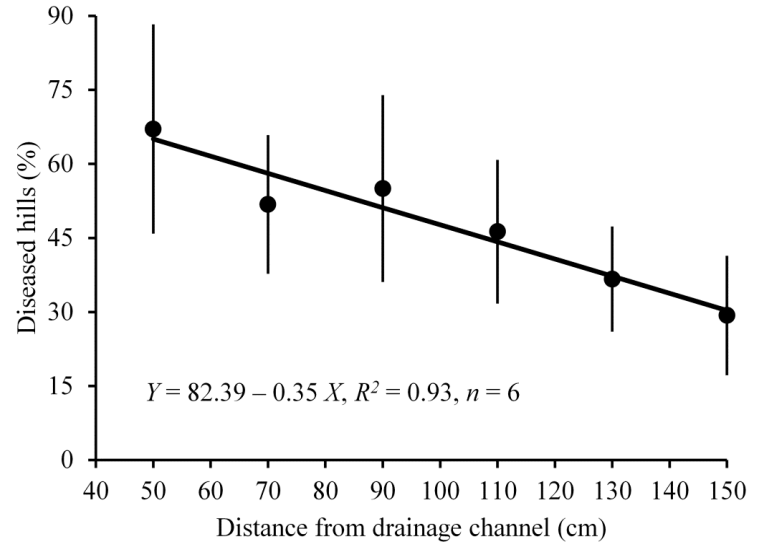

Fig. 7. A regression of percentage of diseased hills against the proximity of the location of the hills from drainage channel in the field $\left(R^{2}=0.93\right.$, intercept $=82.39$, intercept standard error $=5.07$, slope $=0.35$, slope standard error $=0.05, p<0.05, n=6$ )

\section{Probability of Diseased Tillers Per Hill and Smut Balls Per Panicle}

As many as 10 diseased tillers were recorded within a hill. Overall, however, only a limited number of tillers within a hill were diseased. Recorded in 4813 hills in the ecosystem, the probability of occurring 1 diseased panicle per hill was 0.73 ; the cumulative probability of occurring 2, 3 and 4 or less diseased panicles per hill was calculated as 0.90, 0.95 and 0.97, respectively (Fig. 8a).

The number of smut balls per diseased panicle varied between 1 and 67. However, recorded in 1337 diseased panicles, the frequency higher number of balls sharply reduced (Fig. 8b). The probability of occurring 1 ball per panicle was calculated as 0.29 ; the cumulative probability of occurring 4 or less balls per panicle was 0.61 (Fig. 8b). 

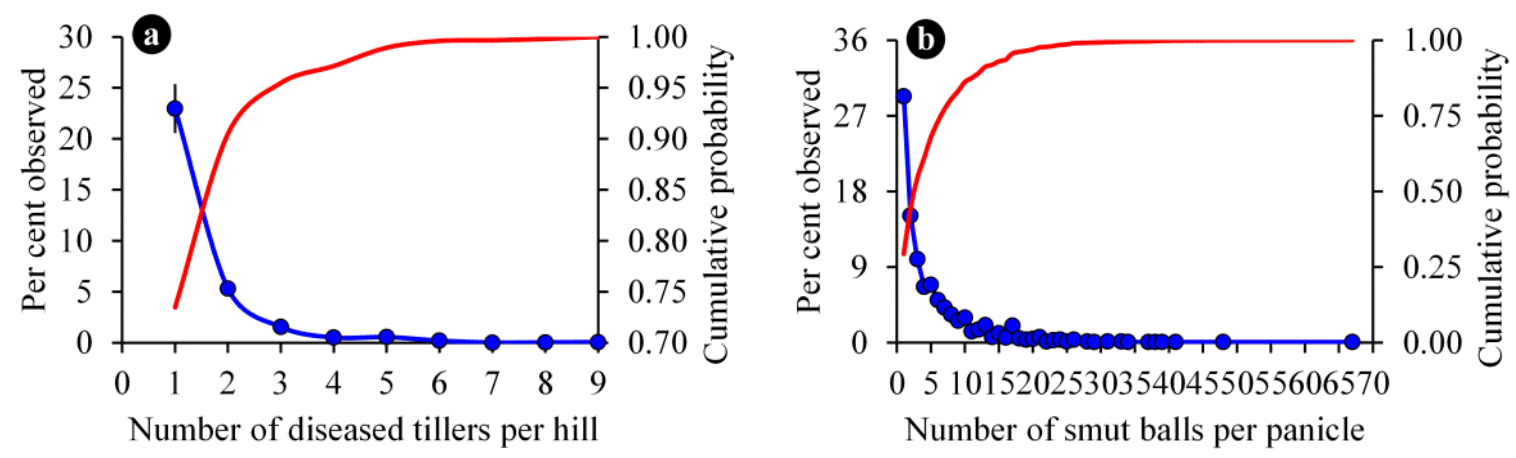

Fig. 8. Observed (filled-circles with line) and cumulative probability (red line) of diseased tillers per hill (a) and number of smut balls per diseased panicle (b) Vertical bar is standard error

\section{Discussion}

In this study, we have analyzed spatial pattern of natural spread of Rice False Smut (RFSm) disease between and within nine fields in an intensive rice ecosystem in Bangladesh. Such analysis, to best of our knowledge, never employed for this pathosystem and it provides significant evidences leading to inferring the nature of the disease spread. As a tool, spatial pattern analysis is often done when spread of a disease from a well-defined inoculum source cannot (Sparks et al., 2008) or difficult to study. RFSm is an example of such a disease. Our knowledge concerning the disease cycle and epidemiology of RFSm is minimal and incomplete or even contradictory (Lee and Gunnell, 1992; Zhang et al., 2014). While there have been "many hypotheses and much speculation" on the disease cycle of RFSm, there remains lack of experimental evidences to prove or disprove those hypotheses (Tang et al., 2013).

Our results show that there was significant variation in disease status between the fields. In spite of the surrounding RFSm infected fields, the disease in Fields 8 and 9 was almost missing, whereas it was very high in Field 4. This indicates field-to-field spread of the disease did not occur. We infer that primary RFSm epidemic is unlikely related to the long distance dispersion of airborne spores (chlamydospores) originating from inseason smut balls. One might argue that infection from field-to-field dispersion of spores did not occur as the crops missed the right stage of infection, which is believed to be around booting stage (Ashizawa et al., 2011; 2012; Tang et al., 2013; Fan et al., 2015). However, this is not likely because rice crop grows in hills producing 10 or more tillers per hill and development of tillers and panicles is asynchronous (Vergara et al., 1990). It takes two weeks or more to complete the cycle of emergence of panicles in a hill. It is therefore difficult to postulate that the reason of not happening field-to-field spread of the disease could be the missing crop stage of infection.
In general, only a few tillers (one or two) within a hill became diseased, as also evident from other studies (e.g., Ikegami, 1962) and this trend was persistent in nine fields we studied. In Fields 2 and 3, there were significant number of hills which produced three or more (as many as 10) diseased tillers. However, this pattern of disease appearance was not consistent across the nine quadrats of the fields (note Fields 2 and 3). Again, given that the tiller production in rice is asynchronous, this findings do not show any definitive evidence on the role of in-season spores (chlamydospores) from smut balls as a source of secondary and/or short dispersal infection in the epidemics, as indicated in some literature (e.g., Chao et al., 2014). This study further shows only a few smut balls (one to three) appeared on a diseased panicle, which is in agreement with other studies (Ikegami, 1962). In previous studies, mode of direct infection of the disease on spikelets and grains (i.e., filled spikelets) were reported (Padwick, 1950). However, this is most likely not the case as supported by Tang et al. (2013), otherwise symptom as smut balls would have been consistently devastating across the diseased panicles.

This study reveals mostly aggregated (Fields 1, 2, 3 and 6) and few random (Fields 4 and 5) patterns of RFSm spread in the ecosystem (Figs. 2 and 5, Tables 1a and $b$ ). The aggregated patterns are indication of localized source of infection. Chlamydospores and ascospores in rice soil are considered as the primary sources of infection (Ikegami, 1963a; Ashizawa et al., 2010; Fan et al., 2015), which suggest the disease is a soil borne. Some studies also suggest the disease could be seed borne (e.g., TeBeest et al., 2010). Although untreated seed were used in this study, the seeds were clean and comparable to "breeders' seed" standard. We physically monitored the whole study area, especially in and around the diseased fields, every week during September to December. With our honest observation, we did not find any evidence of presence of any alternate hosts as reported in some studies (Shetty and Shetty, 1985; 1987; Atia, 2004; Fan et al., 2014). 
Localized infection coupled with lack of infectivity from long- and/or short-distance dispersion of air-borne spores, as revealed in this study, strongly support the notion that soil is the absolute dominant and could be the only source of infection of the disease. However, it remains to be debated on how the RFSm pathogen gets into a rice plant to make itself available for infection. We observed more diseased hills towards the proximity of drainage channels in the fields (Field 3 is classical evidence). Brooks et al. (2010) observed significantly few diseases under furrow irrigation system compared to flood irrigation system in the USA. The question may be raised on whether the spores originating from soil float on surface water (as reported in rice kernel bunt by Chahal (2001)) and translocate through flowing water.

There was a trend but not necessarily a consistent relationship existed that the higher proportion of diseased hills resulted into increased diseased tillers per hill. The question may further be raised on why this has not been consistent? A series of recent papers being successful in causing artificial inoculation at booting stage before heading (e.g. Ashizawa et al., 2012; Tang et al., 2013) led to the opinion that spores (ascospores or chlamydospores) enter into the booting sheath along with water flowing on the top leaves. Guo et al. (2012) view the hypothesis that water flowing brings the primary infection source into the sheath is consistent with the observation that the disease is much more severe when rice heading stage is located in rainy and high humidity days. On the contrary, there is an established theory on the presence of spores in air during rainy weather. The findings of Hirst (1953), that include smut spores, reveal prolonged rain removes most of spores in the air and for a time there are few in the air. Some recent findings reveal that RFSm pathogen can undergo an epiphytic stage producing a large number of conidia, which at booting stage of the crop could enter into the rice sheath with rainwater and infect the developing spikelets (Fan et al., 2014; 2015). In a separate set of literature, it has been reported that RFSm pathogen can infect rice roots and coleoptiles at the seedling stage, leading to asymptomatic colonization of the entire plant (Ikegami, 1962; Schroud and TeBeest, 2005; Zheng et al., 2009 cited Fan et al., 2015; TeBeest, 2010). Besides, there is further report that pathogen colonizes tissues of the growing points of tillers during the vegetative stage of rice growth (Ikegami, 1963b). Many recent literature (for example Chao et al., 2014) are less interested on recognizing this route of entry of RFSm pathogen into rice plant on the ground that no visual smut ball were reported from such an infection. In an astonishing observation, believed to be the first in the world, we recorded smut balls on the panicles of the regenerated tillers (otherwise known as ratoons) in the harvested hills that were previously infected by the disease (Fig. 6). These diseased ratoons were located in various parts of the fields and over $25 \%$ of the diseased hills produced typical visual symptom (i.e., smut ball) on ratoons. The number of diseased ratoons per diseased hill rarely exceeded one. As far as our honest observation, only the diseased hills produced the diseased ratoons. Looking at the cut-heights of the harvested hills, it appears the pathogen had been residing inside the main crop at the bottom part. However, it might well be the case of a new cycle of infection as in the main crop. If this is true, the hypothesis of "water flowing brings the primary infection source into the sheath along with water flowing on the top leaves" is probably not correct as, (i) there was no rainfall recorded during ratoon infection period (midNovember 2014 to early-January 2015) and (ii) most of the symptom producing ratoons either lacked or had degenerated flag leaves.

\section{Conclusion}

This study provides a broad but relatively a clear picture on the epidemiology of rice false smut disease in natural environment. It does not recognize any long- or short-distance primary or secondary sources of infection. It establishes soil as the source of initiation of epidemic. Therefore, the disease management may be directed specific to the fields which are at risk. To assess the risk, development of a soil testing mechanism for quantifying inoculum potential is suggested. Discovery of symptom of the disease on ratoons signals the need for fresh thinking on the actual route of entry of the pathogen into the plant. This information is essential for formulating appropriate management option(s) for the disease.

\section{Acknowledgement}

This study is a part of BN's on-going PhD research. The Bangladesh Agricultural Research Council (BARC) offered a PhD fellowship and the Bangladesh Rice Research Institute (BRRI) granted study leave and provided with research facilities to run the $\mathrm{PhD}$ program-BN deeply acknowledges both BARC and BRRI for that. MUS thank the Department of Agriculture and Food Western Australia (DAFWA) for facilitating a semi-sabbatical arrangement to be involved in the study and BRRI for hosting him. BN is grateful to the Plant Pathology Division of BRRI for assistance in data collection especially through Scientific Assistant Mohammed Nizamul Karim. WJM thanks BRRI for partly sponsoring his visit to Bangladesh. WJM and JG acknowledge DAFWA for providing opportunity to contribute to this project. Authors also thankfully acknowledge constructive criticisms from the reviewer(s) which definitely turned this article into a high quality publication. 


\section{Author's Contribution}

Conceptualizing and designing of the work: BN MUS AHMMH JKB WJM. Facilitating data acquisition: MSK JKB MAL. Collecting data: BN MUS WJM HNB. Analyzing and interpreting spatial pattern: MD. Analyzing and interpreting other data: BN MUS HNB. Drafting the article: BN MUS. Revising the article: JW MD AHMMH MAL HNB MSK JKB. Supervising PhD project: AHMMH MUS JKB.

\section{Ethics}

The authors state that this article conforms to the ethical standards specified by the American Journal of Agricultural and Biological Sciences.

\section{References}

Ashizawa, T., M. Takahashi, J. Moriwaki and K. Hirayae, 2010. Quantification of the rice false smut pathogen Ustilaginoidea virens from soil in Japan using realtime PCR. Eur. J. Plant Pathol., 128: 221-232. DOI: $10.1007 / \mathrm{s} 10658-010-9647-4$

Ashizawa, T., M. Takahashi, J. Moriwaki and K. Hirayae, 2011. A refined inoculation method to evaluate false smut resistance in rice. J. General Plant Pathology, 77: 10-16. DOI: $10.1007 / \mathrm{s} 10327-010-0279-5$

Ashizawa, T., M. Takahashi, M. Arai and T. Arie, 2012. Rice false smut pathogen, Ustilaginoidea virens, invades through small gap at the apex of a rice spikelet before heading. J. Gen. Plant Pathol., 78: 255-259. DOI: 10.1007/s10327-012-0389-3

Atia, M.M.M., 2004. Rice false smut (Ustilaginoidea virens) in Egypt. J. Plant Dis. Protection, 11: 71-82.

Brooks, S.A., M.M. Anders and K.M. Yeater, 2010. Effect of furrow irrigation on the severity of false smut in susceptible rice varieties. Plant Dis., 94: 570-574. DOI: 10.1094/PDIS-94-5-0570

BRRI, 2013. Adhunik Dhaner Chash (Modern Rice Cultivation). Bangladesh Rice Research Institute, Gazipur-1701, Bangladesh (Bangla).

Camann, M.A., A.K. Culbreath, J. Pickering, J.W. Todd and J.W. Demski, 1995. Spatial and temporal patterns of spotted wilt epidemics in peanut. Phytopathology, 85: 879-885.

Campbell, C.L. and I.P. Noe, 1985. The spatial analysis of soilborne pathogens and root diseases. Ann. Rev. Phytopathol., 23: 129-48.

Chahal, S.S., 2001. Epidemiology and management of two cereal bunts. Indian Phytopath., 54: 145-157.

Chao, J., J. Jin, D. Wang, R. Han and R. Zhu et al., 2014. Cytological and transcriptional dynamics analysis of host plant revealed stage-specific biological processes related to compatible riceUstilaginoidea virens interaction. PLoS ONE 9: e91391. DOI: 10.1371/journal.pone.0091391
Fan, J., X.Y. Guo, F. Huang, Y. Li and Y.F. Liu et al., 2014. Epiphytic colonization of Ustilaginoidea virens on biotic and abiotic surfaces implies the widespread presence of primary inoculum for rice false smut disease. Plant Pathol., 63: 937-945. DOI: $10.1111 /$ ppa.12167

Fan, J., X.Y. Guo, L. Li, F. Huang and W.X. Sun et al., 2015. Infection of Ustilaginoidea virens intercepts rice seed formation but activates grain-filling-related genes. J. Integrative Plant Biology.

DOI: 10.1111/jipb.12299

Guo, X., Y. Li, J. Fan, L. Li and F. Huang et al., 2012. Progress in the study of false smut disease in rice. J. Agric. Sci. Tech., A2: 1211-1217.

Hirst, J.M., 1953. Changes in atmospheric spore content: Diurnal periodicity and the effects of weather. Trans. Brit. Mycological Society, 36: 375-393. DOI: $10.1016 / \mathrm{S} 0007-1536(53) 80034-3$

Hughes, G., 1990. Characterizing crop responses to patchy pathogen attack. Plant Pathol., 39: 2-4. DOI: $10.1111 /$ j.1365-3059.1990.tb02469.x

Ikegami, H., 1962. Study on the false smut of rice. V. Seed ling inoculation with the chlamydospores of the false smut fungus. Annals Phytopathological Society Japan, 27: 16-23.

Ikegami, H., 1963a. Occurrence and development of sclerotia of the rice false smut fungus. Res. Bull. Fac. Agric. Gifu Univ., 18: 47-53.

Ikegami, H., 1963b. Studies on the false smut of rice X. Invasion of chlamydospores and hyphae of the false smut fungus into rice plants. Res. Bull. Fac. Agric. Gifu Univ., 18: 54-60.

Kuosmanen, N., T. Kuosmanen and T. Sipiläinen, 2013. Consistent aggregation of generalized sustainable values from the firm level to sectoral, regional or industry levels. Sustainability, 5: 1568-1576. doi: $10.3390 /$ su5041568

Lee, F.N. and P.S. Gunnell, 1992. False Smut. In: Compendium of Rice Diseases, R.K. Webster and P.S. Gunnell (Eds.), American Phytopathological Society, St. Paul, Minn.

Madden, L.V., R. Louie and J.K. Knoke, 1987. Temporal and spatial analysis of maize dwarf mosaic epidemics. Phytopathology, 77: 148-156.

Madden, L.V., G. Hughes and F. van den Bosch, 2007. The Study of Plant Disease Epidemics. 2nd Edn., APS Press, St. Paul, Minnesota, USA. ISBN-10: 0890543542, pp: 421.

Madden, L.V., G. Hughes and M.A. Ellis, 1995. Spatial heterogeneity of the incidence of grape downy mildew. Phytopathology, 85: 269-275.

DOI: $10.1094 /$ Phyto-85-269 
Moreno, A., M. Nebreda, B.M. Diaz, M. Garcia and F.J.S. Salas et al., 2007. Temporal and spatial spread of Lettuce mosaic virus in lettuce crops in ventral Spain: Factors involved in Lettuce mosaic virus epidemics. Annals Applied Biology, 150: 351-360. DOI: $10.1111 / \mathrm{j} .1744-7348.2007 .00135 . \mathrm{x}$

Nelson, S.C. and C.L. Campbell, 1993. Comparative spatial analysis of foliar epidemics on white clover caused by viruses, fungi and a bacterium. Phytopathology, 83: 288-301.

Nessa, B., M.U. Salam, A.H.M.M. Haque, J.K. Biswas and W.J. MacLeod et al., 2015. FLYER: A simple yet robust model for estimating yield loss from rice false smut disease (Ustilaginoidea virens). Am. J. Agric. Biol. Sci., 10: 41-54. DOI: 10.3844/ajabssp.2015.41.54

Padwick, G.W., 1950. Manual of Rice Diseases. 1st End., Commonwealth Mycological Institute, Kew, UK. pp: 198.

Payne, R., 2014. A guide to regression, nonlinear and generalized linear models in GenStat ${ }^{\circledR}$ (17 Edition). VSN International, 5 The Waterhouse, Waterhouse Street, Hemel Hempstead, Hertfordshire HP1 1ES, UK.

Savary, S., N.P. Castilla and L. Willocquet, 2001. Analysis of the spatiotemporal structure of rice sheath blight epidemics in a farmer's field. Plant Pathology, 50: 53-68. DOI: 10.1046/j.13653059.2001.00531.x

Schroud, P. and D.O. TeBeest, 2005. Germination and infection of rice roots by spores of Ustilaginoidea virens. AAES, 540: 143-151.

Sgroi, F., A.M. Di Trapani, M. Foderà, R. Testa and S. Tudisca, 2015. Economic assessment of Eucalyptus (spp.) for biomass production as alternative crop in Southern Italy. Renewable Sustainable Energy Rev., 44: 614-619. DOI: 10.1016/j.rser.2015.01.032

Shetty, S.A. and H.S. Shetty, 1985. A hitherto unrecorded collateral host of Ustilaginoidea virens Cke Tak. Current Sci., 54: 646-647.

Shetty, S.A. and H.S. Shetty, 1987. Role of Panicum trypheron in annual recurrence of false smut of rice. Trans. Brit. Mycological Society, 88: 409-411. DOI: 10.1016/S0007-1536(87)80017-7

Sparks, A.H., P.D. Esker, G. Antony, L. Campbell and E.E. Frank et al., 2008. Ecology and epidemiology in R: Spatial analysis. Plant Health Instructor. DOI: 10.1094/PHI-A-2008-0129-03
Spiertz, H., 2013. Challenges for crop production research in improving land use, productivity and sustainability. Sustainability, 5: 1632-1644. DOI: $10.3390 /$ su5041632

Tanaka, E., T. Ashizawa, R. Sonoda and C. Tanaka, 2008. Villosiclava virens gen. nov., comb. nov., teleomorph of Ustilaginoidea virens, the causal agent of rice false smutnov., comb. nov., teleomorph of Ustilaginoidea virens, the causal agent of rice false smut. Mycotaxon, 106: 491-501.

Tang, Y.X., J. Jin, D.W. Hu, M.L. Yong and Y. Xu et al., 2013. Elucidation of the infection process of Ustilaginoidea virens (teleomorph: Villosiclava virens) in rice spikelets. Plant Pathol., 62: 1-8. DOI: $10.1111 /$ j.1365-3059.2012.02629.x

Taylor, L.R., 1984. Assessing and interpreting the spatial distributions of insect populations. Ann. Rev. Entomology, 29: 321-357.

DOI: 10.1146/annurev.en.29.010184.001541

TeBeest, D., 2010. Infection of rice by Ustilaginoidea virens. Phytopathology, 100: 125.

TeBeest, D.O., A. Jecmen and M. Ditmore, 2010. Infection of Rice by the False Smut Fungus, Ustilaginoidea virens. In: B.R. Wells Rice Research Studies, R.J. Norman and J.F. Meullenet (Eds.), University of Arkansas Agricultural Experiment Station Research Series, Fayetteville, Ark., USA. pp: 70-81.

Testa, R., A.M. Di Trapani, F. Sgroi and S. Tudisca, 2014. Economic sustainability of Italian greenhouse cherry tomato. Sustainability, 6: 7967-7981. DOI: $10.3390 /$ su6117967

Vergara, B.S., B. Venkateswarlu, M. Janoria, J.K. Ahn and J.K. Kim et al., 1990. Rationale for a low tillering plant type with high density grains. Philippines Jr. Crop Sci., 15: 33-40.

Zhang, Y., K. Zhang, A. Fang, Y. Han and J. Yang et al., 2014. Specific adaptation of Ustilaginoidea virens in occupying host florets revealed by comparative and functional genomics. Nature Communications. DOI: $10.1038 /$ ncomms4849

Zheng, D.W., L.P. He, C.M. Meng and D.W. Hu, 2009. The Cytological Evidence on Infection of Ustilaginoidea virens at the Germination Stage. In: Proceedings of the Annual Meeting of Chinese Society for Plant Pathology, Y.L. Peng, Y.Y. Zhu (Eds.), China Agricultural Science and Technology Press, Beijing, China. 